\title{
Response to Commentators
}

\author{
GARY STEINER
}

\begin{abstract}
I. Animals
Animals, their predicament and abuse at the hands of human beings-this is ultimately what we are here to discuss. We have some disagreements and misunderstandings to work through in this discussion, but what we must not forget is that right now animals are suffering egregiously. And I would like to think that we should be able to articulate some clear guidelines for how we may and may not treat nonhuman animals. This is what I am after in my endeavor to articulate clear principles bearing on our treatment of animals, and in my advocacy of the vegan imperative. To advocate this imperative is not to purport to have clean hands; it is not to consider oneself "better" than non-vegans; it is not to assume naively that veganism is equally possible for all human beings in all places and at all times; and it is not to pretend that anyone can "be" a vegan once and for all, without any exceptions. It is to commit oneself very deliberately and selfconsciously to the endeavor to reduce ever more, with each passing day, the amount of violence one (and one's society) inflicts on animals. It begins with specific steps such as, but not limited to, never eating animals or animal products unless one's survival very literally depends on eating them - and I am not sure, but I will wager that no one in this room at this moment is in such a position
\end{abstract}




\section{What is postmodernism, and does it have a place for moral principles?}

One of the things I do in Animals and the Limits of Postmodernism is discuss the notion of moral principles and imperatives - what they are, how they are formulated, how one goes about implementing them, and, perhaps most importantly for the central theme of the book, how principles have been misunderstood at a very basic level by a group of thinkers that are loosely related in terms of what Richard Bernstein calls "the postmodern ethos," an ethos that is "amorphous, protean, and shifting," but in terms of which thinkers such as Foucault, Lyotard, Heidegger, and Derrida are related by their shared critique of the traditional metaphysical notion of the subject, with its assumption that we have access to clear and enduring truths about reality (Bernstein 11). The thinkers that I characterize as "postmodern" move from the historical ideal of Cartesian clarity and distinctness to the opposite pole of what Descartes called "obscurity and confusion." Naturally this is not the way postmodern thinkers such as Derrida characterize their affirmation of the primacy of irreducible multiplicity, but these in fact come to the same thing. Descartes saw our initial confrontation with reality to be a confrontation with a vast and incomprehensible multiplicity of phenomena, a multiplicity that from the standpoint of unreflective experience seemed irreducibly incoherent. The move to clear and distinct insight consisted in a reduction of multiplicity to basic structures, concepts, or insights that disclosed the truth underlying the outward appearance of obscurity and confusion. The thinkers I classify as "postmodern" share a basic suspicion of this attempt at a reduction, on the grounds that it not only distorts the reality that confronts us, but imposes ideologically pernicious assumptions onto reality. For these thinkers, for example, the humanist idea of the equality of all human beings is a strategic conceptual 
distortion that imposes and reinforces the illusion of equality where the underlying reality is one of differential power relations; and one sees attempts at a demystification of this illusion in thinkers such as Marx (with his critique of the German ideology) and Foucault, first with his archaeological investigations and then with his genealogical ones. Another key example of the postmodern challenge to the traditional notion of the subject-more broadly this is a challenge to an assumption that goes back to Greek antiquity-is the challenge to what has come to be known as "human exceptionalism," the proposition that some capacity or set of capacities is not only unique to human beings but renders human beings morally superior to all other beings in existence. For thinkers from Aristotle and the Stoics to John Rawls, the capacity for logos (reason or predicatively-structured language) is unique to human beings, enables them to pursue virtue for its own sake, and thereby renders human beings what Kant at one point calls "the lords of nature," this a hundred and fifty years after Descartes calls human beings "the masters and possessors of nature" (Kant sec. 83, Ak. 431; Descartes, Discourse Part 6). Thinkers such as Derrida challenge this exclusion of animals from the realm of the symbolic, Derrida observing in his lecture course on The Beast and the Sovereign that many non-human animals are "autotelic," which is to say that they set goals for themselves and pursue them on their own initiative, rather than being mere biological reaction devices, as so many traditional thinkers had characterized nonhuman animals (Derrida, The Beast 183; "But as for me" 94). The rejection of the thesis that only humans possess logos is a challenge to the traditional assertion of a hierarchy in which human beings are superior and nonhuman animals and the rest of nature inferior. 
Together with this challenge to human exceptionalism, which includes a challenge to the modern thesis that only human beings are "subjects" and all else in nature mere "objects," the thinkers I am calling postmodern pose a strong challenge to the idea of moral principles that is inseparable from the liberal humanism espoused by thinkers such as Locke, Rousseau, and Kant. The premium postmodern thinkers place on irreducible multiplicity, on what Descartes called obscurity and confusion, has as one of its consequences the impossibility of legitimating, of providing a "transcendental guarantee," for any sort of categorical principle that would purport to have binding authority over anything more than a singular instant. The postmodern appeal to multiplicity is, I argue at length in Animals and the Limits of Postmodernism, implicitly an assertion of the primacy of the singular exception over any claim to general truth or validity, where "general" signifies application to a class of moments, entities, or situations. The singular exception, as Carl Schmitt argued in his theory of the political, is by its very nature beyond or prior to any assertion of the validity of general norms, and indeed cannot ultimately be governed by such norms. To assert the primacy of multiplicity over unity in this way is to foreclose the possibility of articulating principles with binding authority-or, to put the point another way, it is to commit oneself to the proposition that any purported "authority" a given principle may have is simply the reflection of an attempt by one perspective to gain ascendancy over some other perspective. There is no stepping back from our immersion in the field of multiplicity and assessing it, either rationally or in any other way, inasmuch as the assertion of reasons now becomes simply the deployment of just another tool in an endless series of polemical struggles for dominance. 
The way I put this point in Animals and the Limits of Postmodernism is in terms that I borrow from Richard Wolin, namely, in terms of the distinction between a "total" versus an "immanent" critique of reason. Postmodern thinkers undertake a total critique of reason, which means that they reject any ultimate authority of reason in the sense of a faculty that could transcend the influences of power and perspective; they reject Aristotle's ideal of the eternity of nous and the ideal of liberal political and moral principles as well. Liberal thinkers who adhere to a traditional ideal of moral and political principles undertake an immanent critique of reason, which means that they believe in the power of reason to reflect in more than a contingent way on its own nature and limits. It is their total critique of reason that prevents postmodern thinkers from even wanting to articulate moral principles, let alone from attempting to articulate them.

\section{In what sense, then, can postmodernism be "ethical"?}

The answer I give to this question in Animals and the Limits of Postmodernism is that postmodernism finds itself caught in a tragic dilemma between quietism and decisionism, between the paralysis of being able to do no more than observe and document a multiplicity of phenomena, and the assertion of an irreducibly singular choice that cannot be reduced to rational insight and hence cannot be discussed, disputed, or defended so as to satisfy the criteria of anything like Habermasian discursive consensus.

I arrive at this diagnosis of the postmodern condition by devoting the first chapter of Animals and the Limits of Postmodernism to an examination of the thought of Friedrich Nietzsche, who provides the most influential background and impetus to the postmodern turn. Nietzsche's perspectivism, the influence of which is utterly unmistakable in the 
thought of Heidegger, Foucault, Derrida, and, I argue, an entire array of other postmodern thinkers, involves a total critique of reason and ultimately entails an irreducibly polemical conception of discourse-polemical in the literal sense of polemos or war. On Nietzsche's view, the twin ideals of objectivity and individual autonomy, of a space of free, undistorted contemplation from which one can observe and critically assess the influences of culture and nature and take a freely chosen stand on the exigencies of existence, is a fiction invented to serve interests of power. But Nietzsche's critique of subjectivity only begins there. He goes further, proceeding from a critique of Schopenhauer's conception of the world-will and Schopenhauer's ideal of "affirmation and denial of the will" to the radical thesis that the will must be asserted at all costs, including at the cost of the infliction of unbridled violence. Thus Nietzsche's conception of existence is doubly polemical: he sees life in terms of power struggles, and moreover he endorses a way of life in which freedom is nothing more or less than "the affect of superiority in relation to him who must obey" (Nietzsche, "Prejudices" 215). In Animals and the Limits of Postmodernism I argue that the endeavor of a number of postmodern thinkers to detach this pernicious endorsement of violence from Nietzsche's perspectivism is fruitless, that once we have dispensed with anything like the authority of a reason that can transcend particular perspectives we have rendered ourselves unable to give clear reasons why, for example, community is to be preferred to the dominance of the many by the few, or why more generally the peaceful embrace of the other is to be preferred to his or her violent subjection. To capitulate to perspective is to take on all the attendant implications of Nietzsche's naturalism, in particular his polemical conception of relations among humans as well as between human beings and nature. 
When thinkers such as Foucault or Derrida espouse ethical causes, for example when they decry various injustices that are done to women, people of color, animals, and generally to those who do not fit neatly into the dominant paradigm or norms, these thinkers are doing two interrelated things: They are expressing genuinely moral concern, and they are appealing, if only against their own intention, to principles bearing on community and morality-not, however, principles in the sense in which one might consider différance to be a "principle," but principles in the sense of exactly the kind of spatiotemporally decontextualized guidelines for conduct that the appeal to irreducible multiplicity renders incoherent or unavailable to us. When Foucault, for example, undertakes genealogical investigations to shed light on the ways in which social institutions and disciplinary matrices of power have conferred contingent shape and meaning on the self, it is not difficult to see that he and those who conduct research in his spirit are attempting to shed light on specifically ethical problems. But in doing so, these thinkers presuppose some kind of access to concepts, insights, and guidelines that make it possible to see particular practices as pernicious. Genealogy itself does nothing to provide these concepts and guidelines. When I write in Animals and the Limits of Postmodernism that Foucault treats genealogy as a kind of exception to the proposition that all discourses are products of power relations, as if his claims about genealogy were virtually objective statements of the way power in general works, it simply is not sufficient to point out that Foucault acknowledges that all genealogy expresses power relations. There is a difference of level between a discourse that reflects or describes a set of power relations, and a meta-discourse that makes claims about the ways in which discourses on the first level function to articulate and ramify dynamics of power. That 
Foucault makes statements of both kinds is undeniable. What we must seriously call into question is whether his claims about the general nature and dynamics of genealogy are compatible with the blanket assertion, taken over virtually unmodified from Nietzsche, that all discourses are products of perspectives of power and hence not products of some objective standpoint. And if they are compatible, then Foucault is presupposing access to some kind of quasi-objective vision about the way things are and ought to be-quasi in the sense that it may not be absolutely timeless, but nonetheless can transcend the particularity of specific times and places just enough to arrive at assertions that are implicitly offered to the reader as meta-insights that are not simply effects of whatever power dynamics happen to prevail at the particular moment.

What I argue in the second chapter of Animals and the Limits of Postmodernism is that the sorts of ethical claims advanced by thinkers such as Foucault and Derrida presuppose a certain kind of vision. It is entirely fair to say that Derrida focuses his deconstruction of the human-animal boundary in important part on the notion of touch; and in Animals and the Limits of Postmodernism I devote some of my remarks in chapter three to the problematic implications of Heidegger's denial that an animal can possess hands (112). Derrida and a number of other contemporary thinkers are right to challenge the idea that only human beings have access to the rich subjective experience of touch. And by shifting the terms of the discussion from one sense to another, namely from vision to touch, these thinkers quite understandably are trying to shift the terms of the discussion away from the historical focus on $\log o$, with its well-known connection to the capacity for vision, to the shared lived embodiment of human beings and nonhuman animals. ${ }^{1}$ But in shifting the focus of the discussion to the proposition that animals 
participate in the sense of touch, the postmodern thinkers I examine tend to ignore something of vital importance, something that bears upon the capacity for vision: that human beings, unlike most if not all nonhuman animals, are capable of abstract reasoning and the formulation of ethical principles, and that this confers on us important responsibilities that no nonhuman animals can take on. The tradition mistakenly took the human possession of this capacity as an index of our moral superiority over nonhuman animals, and of our supposed natural prerogative to use animals as mere means instead of seeing our cosmic commonality and kinship with them. While I can understand and in fact fully share the postmodern impulse to negate or discredit this traditional claim of exceptionalism, I do not believe that the right way to do this is to characterize the field of experience in a manner that deprives human rationality, and the capacity to formulate and strive to live in accordance with moral principles, of their crucial potential in the endeavor to identify and seek to redress the epic injustices that surround us. To return for a moment to Nietzsche, I argue that Nietzsche takes some of the inspiration for his perspectivism from David Hume, whose anti-rationalism leaves him in the position of reducing ethics from a prescriptive endeavor to a merely descriptive one--this is what we call murder, this is what we call exploitation, etc., without any trans-empirical standpoint to appeal to from which we could make any prescriptive assessments about what really is an injustice and how exactly we ought to redress it-except that, I should note, a fullyformed utilitarianism pops up in Book 3 of the Treatise of Human Nature much in the manner that Pallas Athena was born spontaneously out of Zeus's head. Which is to say that Hume, just like Foucault and Derrida after him, sets forth epistemological premises that entail a merely descriptive relationship to the irreducible multiplicity of reality, only 
to articulate in addition an ethical standpoint that presupposes exactly the kind of autonomous vision that he has just discredited. And if Foucault and Derrida do this unwittingly and entirely against their own avowed intentions, they do it all the same.

As do thinkers such as Levinas, who might not appear to do so inasmuch as they appeal to alterity or the concrete claim of the other rather than to something like irreducible multiplicity. But everything depends on what we mean by alterity or the other. Certainly thinkers such as Levinas are not thinking of the other in the sense of a metaphysically stable entity that confronts us in some clear and straightforward sense; and even to the extent that we might talk of the other as a presence, that presence is simply the outward manifestation of an underlying and irreducibly mysterious process of what Heidegger called unconcealment: the truth of the other is ultimately aletheia not orthotes, inasmuch as it is rooted in and emerges imperceptibly and incalculably from physis. To this extent our fundamental relationship to the other is irreducible to straightforward principles, and as regards animals the problem is compounded by the fact that Levinas, although he equivocates on the question, ultimately excludes animals from the moral community. Bobby may be the last Kantian in Nazi Germany, but he lacks a face. I discuss this fundamental commitment and limitation of Levinas's thought in my first book on animals, Anthropocentrism and Its Discontents (214-17).

\section{What are we to make of the denials of postmodern thinkers that they face the dilemma between quietism and decisionism?}

Any thinker who professes sincere moral concern for her fellow human beings, for nonhuman animals, or for nature faces a serious problem if her starting assumptions 
preclude in advance the prospect of articulating clear moral principles. Characterizing genealogy or différance as a "principle" does nothing to address or overcome this problem. Nor should we ever be willing to take any thinker's claims or assessments of her own ideas as dispositive. Instead we need to subject their claims to rational scrutiny, and we need to make sure that our starting assumptions leave a place for rational critique-and as I have noted, a total critique of reason is not rational critique but instead is a rejection of the very possibility of such critique. We also have to acknowledge that it is troublingly common in philosophy of all stripes for people taking different sides in a discussion to talk past one another rather than confronting each other's logic. This is exactly what Judith Butler does when she blithely rejects deep criticisms of postmodernism of the kind I present in Animals and the Limits of Postmodernism. I tried very hard in that book to give as open and generous a reading of a number of postmodern thinkers as I possibly could; and if in the end I had to conclude that the views of these thinkers are dead ends, it was with a sense of sadness and disappointment rather than one of triumphant glee that I did so. In her blurb for the book, Paola Cavalieri characterizes Animals and the Limits of Postmodernism as "a clear exposition of [the] cultural roots and substantive contents [of postmodernism], together with a sympathetic appreciation of its merits and a lucid assessment of its shortcomings." I came to philosophy through Heidegger and Foucault, having had the great good fortune to study with Hubert Dreyfus at Cal Berkeley. Dreyfus introduced me to Foucault, who was during my Cal days spending a lot of time on the Berkeley campus and lecturing frequently. My first real philosophical inspiration came through reading Heidegger and through reading and interacting with Foucault. I then did graduate work at Yale in the 1980s, when Derrida was spending every spring semester 
lecturing and meeting with students. There was a great deal of excitement surrounding Derrida and his ideas at Yale while I was there, and for a time I was swept up in the enthusiasm. But as I studied, thought, and wrote further, a looming sense began to overtake me that there was something profoundly wrong in the unarticulated assumptions being employed by thinkers such as Foucault and Derrida. This was a shocking, dislocating, and deeply disappointing experience for me, made all the more difficult to process by the fact that I continued to see real insight in these thinkers.

So what are we supposed to do if we encounter what we take to be tragic limits in a thinker or school of thought? Look for excuses not to read those thinkers? If one sees no value in a thinker, there is no need to look for excuses not to read him. And if one recognizes real insight in a thinker, the additional recognition of certain tragic limits is not by itself a reason to stop reading. In fact, I have continued to read, write about, and teach a number of postmodern thinkers including Heidegger, Foucault, and Derrida on a regular basis throughout my career. The reason is that they open me to ways to see and think about the world that enriches my appreciation of the human condition and our relation to the nonhuman. But what these thinkers absolutely do not do is give me ways to formulate anything like clear moral principles. As I argue at length in Animals and the Limits of Postmodernism, if only against their own intention these thinkers leave us in the position of being able to do nothing more than stare at what the young Nietzsche called "a moveable host of metaphors" (Nietzsche, "On Truth and Lies" 84). 


\section{What postmodern thinkers get right, and where they stop short}

When I think of what I find enriching in thinkers such as Heidegger, Foucault, and Derrida, I am drawn to Heidegger's distinction between calculative and contemplative thought, as I believe that it motivates a great deal of postmodern writing and thinking, even though few postmodern thinkers seem completely aware of Heidegger's influence on them in this connection. In the "Letter on 'Humanism'," Heidegger calls for "a step back that lets thinking enter into a questioning that experiences--and lets the habitual opining of philosophy fall away" (261). Heidegger calls this open, questioning form of thinking Besinnung or contemplation, and he contrasts it with the reductive form of thinking that projects a preconceived set of parameters onto reality. Exemplary of calculative thinking is Cartesian-Newtonian subjectivity, with its reduction of nature to spatiotemporal magnitudes of motion subject to universal forces. Heidegger ties this reduction of humanity and nature to subject and object to the modern problem of homelessness, and he conceives of the step back to contemplative thinking as a move toward rethinking the "Aufenthalt des Menschen" or human dwelling in the earth.

Heidegger's call for a step back is for a withdrawal from the kind of thinking that seeks to bring about effects and exercise power over things. Contemplative thought "releases itself into openness" and promises to fulfill the human being's potential to be what Heidegger calls "the shepherd of being" (Heidegger, "Conversation" 68; "Letter" 252). And I believe that this call for a step back from the thinking that calculates and seeks to exercise control over things is a vital part of the human vocation. It is what leads thinkers such as Cary Wolfe to deride the kind of ethical principles I advocate on the 
grounds that such principles "[reduce] ethics to the very antithesis of ethics by reducing the aporia of judgment in which the possibility of justice resides to the mechanical unfolding of a positivist calculation" (Wolfe 69).

There is a kernel of truth in this assessment: As I have argued from my first book, Descartes as a Moral Thinker: Christianity, Technology, Nihilism, the formation of moral commitments is irretrievably dependent on what I call an extra-rational source of meaning; and I believe that this is what Heidegger was after in his suggestion that only contemplative thinking has the potential to open us to a cosmos in which we find ourselves a subordinate part of something greater. But in undertaking a total critique of reason, Heidegger never confronts the problem with which we are left if we conceive of experience such that our deepest moral convictions are neither defensible nor even critically discussable with others; as I argue in Animals and the Limits of Postmodernism, this leaves us in the ethically extremely untenable position in which Kierkegaard's Abraham finds himself: beyond the universal, and hence utterly beyond good and evil.

In my work on animals I have been trying to understand the role of reason in ethical reflection, the vital contribution reason makes even though it is not ultimately the origin of our moral commitments and sensibilities. That origin is, as Elisabeth de Fontenay puts it, "pathocentric," and this means that the task is to think through the mutual interplay of reason and feeling rather than trying to give an absolute priority to either, and rather than trying to discredit one in order to give pride of place to the other. Thinkers such as Heidegger would have us believe that reason must be either instrumental or "contemplative," with no other possibilities at our disposal. I take much of what thinkers such as Foucault and Derrida say as a testimonial to the proposition that 
reason can and does function in yet other ways, even if these thinkers fail or refuse to acknowledge the role of a liberal conception of reason in their own thinking. These thinkers implicitly follow the terms of Heidegger's distinction between calculative and contemplative thinking and make what to me are very clear invocations of contemplative thought in their reflections on injustice. What they, like Heidegger, do not do, is return from the realm of contemplation and employ critical reason to solidify, analyze, and discuss with others the specific guidelines for action that are an indispensable part of the moral life and participation in a genuine moral community. In this connection, dare I cite Descartes, that veritable poster child for the misunderstandings, excesses, and paranoia of traditional philosophy? In the Discourse on Method and in the "Preface" to the Principles of Philosophy, Descartes presents us with a provisional morality to serve us pending the development of a permanent rationally-certified morality, because "action permits no delay" (Descartes, "Preface" 186; see also Discourse, part 3). When Descartes says "action," he precisely does not mean "action" in the sense in which Heidegger thinks contemplative thought constitutes action, nor does he mean "action" in the sense in which one might seek to construe, say, reflections on différance to constitute action (Heidegger, "Postscript" 236; "Letter" 239). Animals are suffering egregiously right now-and all the contemplative thought in the world can do nothing to help them, if we do not return from the Cloud-Cuckoo-Land of contemplation and formulate clear guidelines for the ways we may and may not exercise our wills in the material world. 


\section{A concluding note about moral principles}

There is a temptation to construe principles or imperatives in unduly objectified terms, as we typically do when we think of, say, Kant's categorical imperative. In Animals and the Limits of Postmodernism I argue for a different, less objectified conception of moral principles, one that proceeds from the recognition that principles are regulative notions whose full and final implementation may well be made impossible by the conditions in which we find ourselves. In the face of my call for universal veganism, I am often greeted with the observation that not everyone can be a vegan, or cannot be a vegan as easily as I can be one. As I have argued in several of my books on animals, the vegan imperative is incumbent on anyone whose life does not literally and directly depend on the consumption of animals and animal products. That imperative calls on us to endeavor to make veganism more possible for those who wish to become vegans but who face structural obstacles and the imperative calls on us to endeavor to persuade others in a position to do so that morality requires veganism of them. On the account of principles that I offer in Animals and the Limits of Postmodernism, there is no assumption the application of moral principles is clear and straightforward (that it can be reduced to "the mechanical unfolding of a positivist calculation"), nor that everyone is equally able to implement them. One hardly needs to be postmodern to see that individuals alone cannot solve the horrible predicament of animals, and that institutional-societal measures must be included in our endeavor to release animals from the hell into which we have cast them.

My aim in these remarks has not been to convince you of the rightness of my argument in Animals and the Limits of Postmodernism, but rather to persuade you that if 
you care about animals and especially if you think that postmodernism can shed light on the ethical exigencies that face us, you ought to read the book and make a considered judgment for yourself as to whether the argument I have advanced about the limits of postmodernism is compelling. For my argument in the book is not that postmodernism is not worth reading, nor that it has nothing important to tell us in our reflections on problems of injustice. My argument is that postmodernism, in its various forms, is illequipped to return from the openness of contemplative thought and tell us how to live, in terms sufficiently specific to constitute guidelines for how to treat sentient beings who suffer.

\section{Notes}

${ }^{1}$ The traditional connection between $\log o s$ and vision is detailed in Hans Blumenberg's classic essay "Light as a Metaphor for Truth: At the Preliminary Stage of Philosophical Concept Formation."

\section{Works Cited}

Bernstein, Richard J. "Introduction." The New Constellation: The Ethical-Political Horizons of Modernity/Postmodernity. Cambridge: M.I.T. Press, 1991.

Blumenberg, Hans. "Light as a Metaphor for Truth: At the Preliminary Stage of Philosophical Concept Formation," in, Modernity and the Hegemony of Vision. Ed. David Michael Levin. Berkeley: University of California Press, 1993. 30-62.

de Fontenay, Elisabeth. "Pourquoi les animaux n'auraient-ils pas droit à un droit des animaux?" Le Debat 109 (2000): 138-55. 
Derrida, Jacques. The Beast and the Sovereign, Vol. 1. Trans. Geoffrey Bennington. Chicago: University of Chicago Press, 2009.

—. "But as for me, who am I?" The Animal That Therefore I Am. Trans. David Wills. New York: Fordham University Press, 2008.

Descartes, René. "Preface to The Principles of Philosophy." The Philosophical Writings of Descartes, Vol. 1. Trans. John Cottingham, et. al. Cambridge: Cambridge University Press, 1985.

—. Discourse on Method. Penguin UK, 1968.

Heidegger, Martin. "Postscript to 'What is Metaphysics?'" Pathmarks. Ed. William McNeill. Cambridge: Cambridge University Press, 1998.

—. "Letter on 'Humanism'." Pathmarks. Ed. William McNeill. Cambridge: Cambridge University Press, 1998.

—. "Conversation on a Country Path." Discourse on Thinking. Trans. John M. Anderson and E. Hans Freund New York: Harper Torchbooks, 1966.

Immanuel Kant. Critique of Judgment. Hackett Publishing, 1987.

Nietzsche, Friedrich. Beyond Good and Evil. "On the Prejudices of Philosophers." Basic Writings of Nietzsche, sec. 19. Trans. Walter Kaufmann. New York: Modern Library, 1992.

—. "On Truth and Lies in a Nonmoral Sense." Philosophy and Truth: Selections from Nietzsche's Notebooks from the Early 1870's. Ed. and trans. Daniel Breazeale. Atlantic Highlands, N.J.: Humanities Press International, 1992.

Steiner, Gary. Descartes as a Moral Thinker: Christianity, Technology, Nihilism. Amherst, N.Y.: Prometheus/Humanity Books, 2004

-. Anthropocentrism and Its Discontents: The Moral Status of Animals in the History of Western Philosophy. Pittsburgh: University of Pittsburgh Press, 2005.

—. Animals and the Limits of Postmodernism. Columbia University Press, 2013.

Wolfe, Cary. Animal Rites: American Culture, the Discourse of Species, and Posthumanist Theory. Chicago: University of Chicago Press, 2003. 